\title{
Choice and Coercion in East Asian Exchange Rate Regimes
}

\section{Randall Henning}

\begin{abstract}
This paper examines the exchange rate regimes of East Asian countries since the initial shift by China to a controlled appreciation in July 2005, testing econometrically the weights of key currencies in the implicit baskets that appear to be targeted by East Asian monetary authorities. It finds, first, that Malaysia, Thailand, Singapore and the Philippines have formed a loose but effective "renminbi bloc" with China, and that South Korea has participated tentatively since the global financial crisis. Second, the emergence of the renminbi bloc in terms of the exchange rate has been facilitated by the continued dominance of the US dollar as a trade, investment, and reserve currency. Third, exchange rate stabilization is explained by the economic strategies of these countries, which rely heavily on export development and financial repression, and the economic rise of China. Fourth, analysts should specify the exchange rate preferences of these emerging market countries carefully before drawing inferences about Chinese influence within the region.
\end{abstract}

\section{JEL Codes: F31, F33, F36, F4, F5}

Keywords: exchange rates, exchange rate regimes, East Asia, Chinese exchange rate policy, renminbi bloc, East Asian regionalism, dollar standard, monetary power

C. Randall Henning, visiting fellow, has been associated with the Peterson Institute for International Economics since 1986. He is Professor of International Economic Relations at American University's School of International Service and specializes in global economic governance, international and comparative political economy, and regional integration.

Note: This paper was prepared for the project on "Power in a Changing World Economy: Lessons from Emerging Asia," which was sponsored by National Cheng-Chi University, Taiwan, and organized by Benjamin J. Cohen (University of California, Santa Barbara) and Eric M. P. Chiu (National Chung Hsing University). I wish to acknowledge comments by Benjamin J. Cohen, David Andrews, Miles Kahler, William Grimes, Jeff Chwieroth, Thomas Rumbaugh, Thomas Willett, and the other contributors to the project. I am grateful to Mahmud Yesuf for advice on the econometrics and Saori Katada for comments on this paper and our broader collaboration on these subjects. I thank Martin Kessler for excellent research assistance and am alone responsible for any errors or omissions. Comments are welcome at henning@ piie.com.

Copyright (C) 2012 by the Peterson Institute for International Economics. All rights reserved. No part of this working paper may be reproduced or utilized in any form or by any means, electronic or mechanical, including photocopying, recording, or by information storage or retrieval system, without permission from the Institute. 


\section{SECTION ONE: INTRODUCTION}

The exchange rate policies of East Asian states have far-reaching ramifications for international relations within the region, for their relations outside the region, and for the structure of the world economy. Many Asian states have somewhat famously kept their currencies competitively valued through soft pegging to (often undisclosed) currency baskets. (Dooley, Folkerts-Landau, and Garber 2003; McKinnon 2005; Cohen 2008; and Eichengreen 2011, among others). Although the US dollar is weighted heavily in these baskets, the currencies of several Southeast Asian countries tend to exhibit increasingly greater stability vis à vis the Chinese renminbi than vis à vis the US dollar (see also Volz 2010 and Cavoli and Rajan 2009). These currencies are in essence floating jointly against the dollar, albeit in a loosely managed way. The Japanese yen and Korean won follow a different pattern, floating much more flexibly against both the US dollar and the other Asian currencies, though the won has tracked the renminbi somewhat more closely since the global financial crisis. ${ }^{1}$

This paper examines the determinants of the national exchange rate regimes in these states with two purposes in mind, one explanatory and the other conceptual. With respect to the explanatory purpose, it seeks to explain the choice of several Southeast Asian countries to shadow the renminbi and that of others to float. What in particular is the importance of power relative to preferences in configuring the policies of these governments? The rapid growth of China and its role as a competitor for both trade and foreign direct investment loom large, but these factors should be conceptualized with care. The fact that some degree of regional stability is being achieved by stabilizing against the dollar also presents a puzzle.

The following section examines the currency policies of the 13 members of the ASEAN+3 (the Association of Southeast Asian Nations, plus China, Japan, and South Korea) group plus Hong Kong and Taiwan over the course of the last decade and the pattern of exchange rate movements over that period. It conducts an econometric test of the weights of the key currencies (US dollar, Japanese yen, euro, and Chinese renminbi) in the baskets to which Southeast Asian countries softly peg. This section argues that the renminbi has become more important than the US dollar as a reference and anchor for the exchange rate policies of these countries_ a notable shift over the course of the last decade.

The third section discusses the role that power and agency play in the choice of these exchange rate regimes. The discourse among scholars emphasizes the historical dominance of the dollar, the bypassing of the Japanese yen, the rise of China, and the potential for future regional dominance of the renminbi. The international role of the US currency has constrained Asian countries to invoice in the

1. Additional contributions to the growing literature on Asian exchange rates include Chung and Eichengreen 2009; Eichengreen 2004 and 2007; Goldstein and Lardy 2005; Hamada, Reszat, and Volz 2009; He 2011; Henning and Khan 2011; Katada 2004 and 2008; Kawai and Takagi 2005; Kawai 2007; Ogawa and Ito 2002; Ogawa 2007; Park and Song 2011; Pauly 2011; Volz 2009; Willett, Oh, and Yoon 2004; Willett et al. 2011; and Williamson 2005. 
dollar, purchase dollar assets, and shadow the dollar in exchange rate policy_as one of the prominent narratives goes - with the consequence that the Federal Reserve's policy of quantitative easing disrupts monetary conditions in Asia. Reviving the Triffin dilemma, some Asian analysts note that the needs of the international monetary system are likely to come in conflict with the national interest of the issuer of the dominant international currency. On this reasoning, Chinese authorities have advocated exploration of a dramatic expansion of the use of the International Monetary Fund's (IMF) Special Drawing Rights (Zhou 2009) and sought to expand the international role of the renminbi (Cohen forthcoming). This narrative is infused with allusions to currency power and this subject might, at first glance, seem to be a natural candidate for the application of "structural" concepts of power. But, as I have argued with Katada (Henning and Katada forthcoming), domestic political economy has been fundamental in explaining the exchange rate policy choices of China and its regional neighbors.

The fourth section of the paper examines the opposite proposition that Chinese (not US) structural power explains the exchange rate regime choices of Southeast Asian states. While the growth of the Chinese economy is indeed important to explaining the currency choices of its regional neighbors, this section argues, other conceptualizations capture these effects better than structural or second-face concepts of power.

The fifth section draws lessons from the review of national exchange rate regimes for the definition, operationalization, and usefulness of alternative conceptions of power. Power as resources, structural power, and soft power vie for the affections of power analysts. The section probes the usefulness of these alternative conceptions, particularly their ability to provide a pathway to testable causal claims about power relative to alternative explanatory factors. It stresses (1) the importance of pinning down preferences of states before attempting to examine whether they are advanced or compromised by influence attempts, and (2) the collateral damage to positive analysis of soft power concepts. The final section summarizes the main conclusions.

\section{SECTION TWO: SHIFTING EXCHANGE RATE REGIMES IN EAST ASIA}

Analysis of the exchange rate policies of East Asian countries begins with a clear description of them; unfortunately, that is not a simple matter. First, we cannot take the declarations of countries about their national currency regimes at face value; those policies are largely opaque and sometimes misrepresented. Second, there is substantial variation in the national regimes across countries and over time. Nonetheless, a pattern emerges from the exchange rate data over the last decade: Southeast Asian monetary authorities have largely shadowed the renminbi as the Chinese currency has floated upward against the dollar. This pattern can be identified in two ways: (1) the cumulative movement in exchange rate levels since July 2005; (2) econometric estimates of the weights attached to the implicit currency baskets of these authorities. 


\section{Cumulative Movements}

During the decade prior to July 2005, the renminbi was more or less fixed to the US dollar. During that period, Southeast Asian currencies fixed or floated against the dollar and renminbi similarly. When China began its controlled upward float against the dollar in mid-2005, Southeast Asian countries confronted a choice between pegging softly to the dollar or to the renminbi, or to some basket in which they both had significant weights. The governments of the larger emerging market countries in Southeast Asia generally chose to follow the renminbi-more loosely during the first period of managed floating until July 2009, then more tightly during the second controlled float after June 2010. Since mid-2005, the nominal value of the renminbi has risen about 32 percent against the dollar.

Figure 1 displays the bilateral movements of East Asian currencies against the US dollar over that period, July 2005 to March 2012. The figure shows in particular that the cumulative movements of the Malaysian ringgit, Philippine peso, Thai baht, and Singapore dollar have been much larger against the American than against the Chinese currency-less than 5 percent against the renminbi in each case. The Indonesia rupiah and New Taiwan dollar, by contrast, have moved less than 10 percent against the US dollar, to which the Hong Kong dollar is fixed. Although changes in the rupiah now seem to match changes in the currencies of Indonesia's neighbors, the figures show that Southeast Asian currencies have separated into two groups, one associated with the US dollar, the other with the renminbi.

Figure 2 shows a similar pattern in the movement of bilateral real exchange rates, calculated using the consumer price index. The Chinese renminbi has appreciated roughly 40 percent in real terms against the US dollar since July 2005. The Thai baht and Singapore dollar have followed it very closely. The Malaysian ringgit, Philippine peso, and Indonesian rupiah have followed it somewhat more loosely, but still within 10 percent and far more closely than they have the US dollar. The Hong Kong and New Taiwan dollars have followed different paths. Overall, nonetheless, the pattern of real exchange rates also suggests the emergence of a "renminbi bloc."

\section{Estimated Weights in Currency Baskets}

The opacity of national exchange rate regimes in East Asia has spawned a cottage industry of international economists who estimate the weights of major currencies in the targeting practices of these monetary authorities. Frankel and Wei (1994) are credited with initiating a series of studies, followed by McKinnon and Schnabl (2004), Frankel and Wei (2007), Shu (2010), and Frankel and Xie (2010), among a number of others. ${ }^{2}$ These studies first identified a strong weight for the US dollar and attempted to track changes in the weight over time. But not until a substantial period had elapsed, during which the Chinese

2. Including, Shu, Chow, and Chan 2007; Ito 2008; Volz 2010 (chapter 7, annex 9); Girardin 2011; Kawai 2011. 
currency moved separately from the dollar, were these techniques able to estimate the extent to which East Asian authorities have targeted the renminbi. This paper conducts these estimates, updating this analysis through 2011.

The basic method of estimating the weights of important currencies in the implicit baskets of the currency authorities uses ordinary least squares (OLS) regressions on the first differences of the logged values of the bilateral exchange rates. The Special Drawing Right (SDR) serves as the numeraire (following Frankel and Xie 2010). Here, these regressions are conducted on 12 years of daily data. The time series is broken into four periods corresponding to structural breaks defined by changes in the Chinese exchange rate regime: the peg to the dollar until July 21, 2005; the managed float until July 2009; the repegging until June 2010; and resumption of the crawling peg thereafter. For the periods during which the renminbi was fixed to the dollar, the implicit basket does not include the renminbimulticollinearity being an insuperable problem. For the periods in which the renminbi moves against the dollar, the renminbi is included in the regression.

Tables 1 through 4 report the regression results. Table 1 confirms the results of other studies, that the weight of the US dollar was very high prior to mid-2005. McKinnon and Schnabl (2004) thus revived the term "dollar standard" to describe the regional regime during this period. The Japanese yen held significant weights in the implicit baskets for the Korean won, Philippine peso, Singapore dollar, and Thai baht. A 1 percent appreciation of the Japanese yen, for example, was associated with a 0.204 percent appreciation of the Singapore dollar. The proportion of the variation that is explained by the movements of these three currencies differs substantially from one Asian currency to the next, however.

Table 2, which covers the period of the first managed float of the Chinese currency, introduces the renminbi into the model as a regressor and reports substantial and statistically significant weights in the implicit baskets of the Malaysian ringgit, Singapore dollar, and New Taiwan dollar. The weights for the US dollar have fallen substantially in each case. Table 3 reports the results when the renminbi is repegged during July 2009 through June 2010, removing the Chinese currency from the model. It shows weights for the US dollar that are significantly lower than during the pre-July 2005 period for the ringgit, peso, and the Singapore and New Taiwan dollars, but higher for the baht and rupiah. Pertaining to the period June 2010 through December 2011, table 4 reports weights on the renminbi that are higher than the previous renminbi float for the ringgit, peso, and the baht, similar for the New Taiwan dollar, and somewhat lower for the Singapore dollar. The Korean won also shows a stronger weight on the renminbi. The rupiah, in contrast to the other currencies and its own movement during 2005-09, has recently followed the movements of the US dollar fairly closely.

Several overall points can be distilled from these findings. First, the weight of the dollar in these implicit baskets is broadly declining, while that of the renminbi is increasing. Second, the weight of the 
renminbi in the baskets for four of the main Southeast Asian currencies plus the New Taiwan dollar now appears to be greater than the weight of the US currency. Third, the Indonesian rupiah exhibits much more independence from both currencies than do the currencies of its regional neighbors. Fourth, these findings are consistent with the cumulative change in the bilateral nominal exchange rates against the renminbi and dollar since July 2005.

Consider a couple of alternative interpretations of these results. One objection might be that, given these countries' interdependence in "Factory Asia," we would expect their currencies to move together in response to common shocks (such as demand for their exports in the United States and Europe and movements of oil prices). Co-movement of the exchange rate, in this view, is no more collusive than the co-movement of the US and Canadian dollars. This comparison is misplaced for two reasons, however. First, capital markets are not integrated in East Asia as are US and Canadian capital markets. Second, East Asian authorities intervene regularly to manage their rates, while the United States and Canadian authorities intervene very rarely_market exchange rates in Asia represent deliberate policy to a much greater extent.

Another objection could be that Asian monetary authorities are actually targeting a weighted basket of Asian currencies approximated by the Asian Currency Unit (ACU). The baskets in the regressions reported here, in this view, are mis-specified. Girardin (2011) in fact argues that since 1999 Southeast Asian countries have not given up pegged exchange rates; they have instead switched from pegging to the US dollar to pegging to baskets that weight regional currencies fairly heavily. However, these countries might simply be splitting the difference in the divergent movements of the US dollar, renminbi, and yen. It would not be plausible to suggest that these authorities are literally targeting the ACU, as it is an index in the minds of exchange rate analysts with no official standing. Asian countries might achieve more stability in their effective exchange rates by targeting the ACU than by targeting the major currencies-a significant finding - but the prospect of Asian authorities adopting the ACU as a common basket for soft pegging is at best uncertain.

In summary, Southeast Asian currencies have tended to shadow the renminbi during its period of undervaluation against the dollar and show an increasing tendency to move with the renminbi as the Chinese currency appreciates gradually against the dollar. While the Japanese yen and Korean won exhibit more independent floating, the main Southeast Asian currencies appear, tentatively, to be participating in a "renminbi bloc," with the won tracking the renminbi as well since the globlal financial crisis. This observation highlights a significant paradox: Southeast Asian monetary authorities are doing so while at the same time the role of the US dollar as an international currency in other respects within the region remains robust. The next section addresses possible explanations for this paradox. 


\section{SECTION THREE: POWER AND AGENCY}

Scholarship in IPE often speaks of "three faces" of power (Bachrach and Baratz 1962; Lukes 1974; Cohen and Chiu, forthcoming). What light does East Asian currency experience shed on power analysis and the fashion in which International Political Economy (IPE) theorists conceptualize power and agency? This section compares the explanatory value of structural power and domestic political economy analysis.

\section{Structural Power}

The introduction to this volume reviews what have been dubbed by previous analysts as the "three faces" of power (Bachrach and Baratz 1962, Lukes 1974). International monetary affairs might seem to be a natural realm for "second face" conceptions of power or "structural power," as Susan Strange $(1986,1988)$ described this concept. She developed her concept, after all, when analyzing the international monetary system. Several of her successors have sought to formulate the concept more rigorously (see, for example, Guzzini 1993, Palan 1999). Eric Helleiner (2006) honed the concept specifically for international monetary relations and Helleiner (2009) and Kirshner (2009) drew upon it when addressing the international role of the dollar. Given the rise of Asia, therefore, currency relations within the region would seem to be a "crucial case" for this approach to power analysis: If structural approaches are useful, we would expect them to be useful here.

Structural power was famously, if recursively, defined by Strange as:

The power to shape and determine the structure of the global political economy within which other states, their political institutions, and their economic enterprises, and (not least) their scientists and other professional people have to operate; structural power, in short, confers the power to decide how things shall be done, the power to shape frameworks within which states relate to each other, relate to people, or relate to corporate enterprises. (Strange 1988, 24-25; quoted in Helleiner 2006, 74)

Helleiner $(2006,75)$ points out that Strange intended to develop a concept of power as control over structures instead of control over other states directly. Cohen (1977, 54-56) defined structural power as "the ability to gain by rewriting the rules of the game." In these formulations, power can be exercised either intentionally or unintentionally.

The approach has been criticized for a paucity of testable propositions, in the absence of which it has not produced a research program that could be fairly described as cumulative. Precisely what capabilities enable a state to change or sustain the rules of the game? Exactly which rules are important? Re-specifying the structural power approach as a causal theory and fashioning falsifiable hypotheses would be a 
substantial contribution to power analysis. However, the question naturally arises as to whether this can in fact be done. Strange herself eschewed formulations of structural power that could be formally tested (Palan 1999, Keohane 2000).

Economists have described the incentives that the international monetary system applies to exchange-rate policy choice. The network externalities associated with the international role of the dollar creates compelling incentives to perpetuate the dollar standard in East Asia. Asian trade, including intraregional trade, is dominated by the US dollar. Chinese and Southeast Asian exporters would face a commercial disadvantage if they demanded invoicing in local currency. Governments and firms in the region often cannot borrow in local currency either ("original sin"), or of course lend in it yet ("conflicted virtue"). As a consequence, so the argument goes, they must also weigh the dollar heavily in exchange rate policy and accumulate dollar reserves — at least, doing otherwise would be costly (Dooley, FolkertsLandau, and Garber 2003; McKinnon 2005 and 2013). Moreover, countries accumulating reserves for precautionary reasons would want to hold the currency for which exchange convenience is greatest in a financial crisis or liquidity squeeze, the US dollar.

But we should disaggregate these arguments and the effects of currency use on exchange rate regime choice. What actions on the part of Southeast Asian countries does the international currency "structure" dictate and what actions does it not dictate? The dominance of the dollar creates incentives for small and medium powers to invoice in dollars and hold dollars in reserves in order to prevent disorderly and excessive exchange rate fluctuations. It creates incentives for precautionary reserve holdings in US dollars. It does not dictate, however, the maintenance of undervalued currencies or the accumulation of reserves beyond the amounts necessary for exchange rate stabilization (around equilibrium rates) and crisis contingencies - the most important and debated aspects of currency practices within the region over the last decade.

East Asian countries have accumulated foreign exchange reserves considerably beyond the quantities necessary for either purpose (Goldstein and Lardy 2008). These excess reserves magnify the costs of adhering to the dollar standard. Those costs arise in several forms: (a) the interest rate differential between the reserve holdings and central bank liabilities issued to purchase dollars; (b) financial repression in the course of sterilization operations; (c) the threat of inflation and asset price bubbles arising from liquidity injections from currency interventions that are not sterilized; and (d) capital losses on reserve holdings when the dollar depreciates relative to the local currency. In addition, we should add the economic costs associated with favoring the tradable goods sector at the expense of the non-tradable sector through undervaluation.

Why would these states accept these costs, with active participation and evident enthusiasm? A "structural" or "second face" explanation does not appear well suited to answering this question for two 
basic reasons. First, in the original formulation of the structural approach, the international role of the dollar eased constraints on the financing of current account deficits and thus macroeconomic policy of the issuer. The experience in Asia over the last decade turned this argument on its head: Foreign exchange intervention by China and other countries led to unprecedentedly large official investments into US Treasury, government-sponsored corporations (GSCs) and even corporate securities, and sustained the role of the dollar. These inflows were no doubt welcomed by many firms and perhaps some sectors in the United States. But they compromised the ability of the Federal Reserve to influence long-term interest rates and helped to fuel the financial market and real estate bubble prior to the 2008 crisis (Bergsten and Gagnon 2012). Senior US officials repeatedly pressed Chinese officials to reduce their purchases and allow the renminbi to appreciate faster. Rather than conferring an "exorbitant privilege" on the United States, allowing the United States to exploit others through "rules of the game" that it had written, the international role of the dollar made the country vulnerable to free-riding and even abuse of those rules (Goldstein 2006).

Second, the structural power approach does not account for change in exchange rate regimes: As presently formulated, these approaches predict continuity. Strange originally developed and applied the concept to explain the perpetuation of the international role of the dollar, after all, and the ability of the United States to operate relatively unconstrained policies in the post-Bretton Woods environment despite (premature forecasts of) hegemonic decline. This approach cannot explain the shift from soft-pegging to the dollar to shadow-pegging to the renminbi within the context of the continued dominance of the dollar as an international currency in East Asia.

\section{Domestic Politics and Preferences}

Rather than driven by structural power inherent in the international monetary system and role of the US currency, the exchange rate regime choices of East Asian states and the shift in these choices over the past decade are better interpreted as a reflection of preferences and the growing importance of China in the East Asian economy. Those preferences are in turn established by domestic political economy: the political dominance of the traded goods industry, especially in China, and widespread internal financial repression in East Asian countries (Henning and Katada 2012). For East Asian states, accumulating dollar assets and maintaining low-valued currencies served the twin purposes, respectively, of intermediating investment in external assets and maintaining export growth.

For Southeast Asian states, these effects were reinforced by competition with China over trade and foreign direct investment. The spectacular economic growth of China, its importance within "Factory Asia” and its competitiveness as a trading partner and as a magnet for foreign direct investment made giving greater weight to the renminbi in their currency policy a natural response on the part of Southeast Asian monetary authorities. 
Exchange rate cooperation has been pronounced in East Asia-first when maintaining low levels of valuation against the dollar and then when appreciating jointly_but has taken a highly informal, non-institutionalized form. Moreover, the widespread use of the US dollar as an international currency has been integral to Asian countries' ability to coordinate by adjusting rates in this way. Specifically, the dollar provided a common point of reference, a focal point for coordination, and circumvented Sino-Japanese rivalry that would have blocked collective decisions on joint pegging to a common basket (Henning and Katada forthcoming). Common use of the dollar reduces the costs of transacting cooperation among East Asian states.

The relationship between China and its Southeast Asian neighbors is distinctly asymmetrical and takes place with little or no explicit communication. It can be modeled as a Stackelberg leader-follower game. China chooses its currency regime, ${ }^{3}$ moving first, and the Southeast Asian authorities respond. China might anticipate the response of Southeast Asian countries when choosing its exchange rate against the US dollar, but the weight given to this consideration is unknown and would seem to be dominated by Chinese and American economic factors.

\section{SECTION FOUR: CHINESE STRUCTURAL POWER?}

If the convergence of Southeast Asian currencies on the renminbi exchange rate is not a manifestation of US structural power, could it be the work of Chinese structural power? This paper has already argued that China's economic growth has contributed to the shift in the weight of the renminbi in the currency baskets of Southeast Asian countries. China's spectacular growth in general gives Beijing more resources with which to influence the policies of others within the region and beyond, both directly and indirectly through markets, when and if Chinese authorities choose to use them (treatments of monetary power and the rise of China include Kirshner 2003, Andrews 2006, Grimes 2009, Subramanian 2011, and Cohen and Chiu forthcoming; on the renminbi's impact on exports of other countries, see, Mattoo, Mishra, and Subramanian 2012). Some might suggest, therefore, that a structural-power interpretation is apt: Chinese growth would appear to create a structure of incentives that guides Southeast Asian monetary authorities to shift currency practices. In this perspective, Chinese authorities would not need to manipulate these incentives deliberately for us to recognize that this form of power is at work.

However, analysts of power confront a choice between placing factors such as the growth of China into a conceptual basket labeled "power" and one labeled "preference determination." I believe that the field is better served-in terms of formulating a testable hypothesis on which cumulative research can be based-by analyzing these effects through the lens of preferences. Structural power arguments come up

3. Excellent treatments of Chinese exchange rate policy include Liew and Wu 2007, Steinberg 2012, and Steinberg and Shih 2012. 
short when applied to China, just as when applied to the United States, for four empirical and conceptual reasons.

With respect to the analytical approach, first of all, the increase in the economic size of China alone cannot explain the exchange rate policy choices of other Asian states even in principle. The domestic political economy of Southeast Asian countries is critically important. Had their domestic political structures favored the non-tradable sector over the tradable sector and abandoned financial repression, Southeast Asian monetary authorities could well have accepted substantial currency appreciation against the renminbi as well as the US dollar. A power explanation that does not pin down state preferences is incomplete.

Second, with respect to the facts on the ground, we have very little if any direct evidence of Chinese officials' desire to have the currencies of Southeast Asia shadow the appreciation of the renminbi. This is not simply because Chinese officials might be discrete. The pattern of exchange rate policies that has emerged is not necessarily optimal for China, given preferences as Chinese policymakers have defined them. Chinese exports would have been better served by independent floating on the part of Southeast Asian states; in the absence of foreign exchange intervention, Southeast Asian currencies would have appreciated not only against the dollar but against the renminbi as well. The actual outcome does not clearly match a Chinese power explanation.

Third, as discussed in the previous section, coordination and stabilization within the renminbi bloc relies on the intermediating role of the US dollar. The pattern of exchange rate policies that we witness in East Asia would be far more difficult, if not impossible, to achieve in the absence of the prevalent role of the US currency. This creates a glaring logical conflict with earlier formulations of structural power of the United States in international monetary affairs, such as those championed by Strange, in which the role of the dollar, international capital mobility, and dominance of American financial intermediaries would be expected to strongly favor the United States.

The fourth objection relates to intentionality and agency. If an effect of globalization cannot be manipulated and is not intended, then it does not seem to be usefully characterized as "US structural power" or "Chinese structural power." It is rather a set of incentives and disincentives that inhere in the pattern of international economic interdependence within the international trade and financial system that are disembodied from individual states. Both the United States and China can suffer as well as profit from, for example, international capital mobility. These forces are important to shaping policy, but attributing ownership to a particular country would suggest that they somehow serve it in a consistent manner, which is not the case here.

We should indeed be mindful of the patterns of incentives conferred by globalization and economic interdependence. But we must be careful how we conceptualize them. My conceptualization of the 
"exchange rate weapon" revolves specifically around the incentives for policy adjustment created, for example, by a currency appreciation in the face of international conflict over macroeconomic policies (Henning 1998 and 2006). In the cases cited in that work, international capital flows and the operation of the foreign exchange market are harnessed directly to the objectives of the United States, and are under at least partial control of US authorities, and underlying preferences are specified separately from these incentives. ${ }^{4}$ The latter-the independent specification of preferences—is particularly important.

\section{SECTION FIVE: PREFERENCES IN POWER ANALYSIS}

Debates about power in East Asian currency relations serve to remind political scientists of a general principle: We cannot analyze power in isolation from actors' preferences and should always specify them when examining it. Analysts sometimes overlook this step in the rush to identify the sources of power and the channels through which it operates. Unless we can first identify states' preferences, however, we cannot know whether "A induces B to do something that B would not otherwise do." Knowing what B would do in the absence of any influence attempt by $\mathrm{A}$, as set by its preferences, is a necessary precursor.

More fundamentally, if preferences are not in at least partial conflict, then power analysis is not particularly relevant. Thus, establishing preferences is analytically prior to invoking power and the two, preferences and power, should be used in conjunction. Moravcsik (1997 and 2008) advocates such a two-step sequence in building multi-causal explanations. Confusion in the contemporary Asian discourse about whether or not China freely chose its exchange rate regime in the 2000s highlights the importance of pinning down preferences first.

Specifying state preferences is not always easy, of course. States are not unitary actors, constituent social groups have differentiated preferences, and policy is naturally contested. A full explanation must describe how some interests dominate others in the internal aggregation process, as well as how external factors impact the interests of domestic groups. Fortunately, domestic and comparative politics provide a number of models for doing so, including social-identity, institutional, rent-seeking, and open economy paradigms. It is better to take advantage of them in a two-stage process rather than attempting to shoehorn preferences and power together into a single analysis.

4. In their important article on the "second face" of hegemony, James and Lake $(1989,4)$ argue that Britain's repealing the Corn Laws in the middle of the nineteenth century created incentives for the United States to liberalize trade as well. Stolper-Samuelson effects swung the position of Western states behind tariff reduction over the course of the 1840s. In their conception, "This is a 'Trojan horse' strategy in which the hegemon changes the constellation of interests and political power within other countries in ways more favorable to its own interests." As elegant as it is, however, their interpretation leaves open the possibility that Britain's own interests are decided by the same potential gains offered by the international prices of tradable goods as operate on the US position on trade policy — which blurs a line between preferences and influence that should be kept as clean as possible — and they are ultimately agnostic with respect to the deliberateness with which British authorities target US policy with these effects. 
As a corollary to the notion that preferences are analytically prior to power analysis, it is critical to keep preferences and power conceptually distinct. If they are conflated, we cannot examine the independent impact of either on the other or on third variables. In this connection, consider "soft power." Joseph S. Nye named the concept in order to draw attention to the importance of non-tangible factors influencing interstate relations: "Soft power rests on the ability to shape the preferences of others to want what you want" (Nye 2008, 29). Nye $(2010,2011)$ takes this one step further by introducing "smart power," the use of hard and soft power in combination.

The problem with these concepts is that they obliterate the distinction between power and preferences. Although they contribute to policy debates, soft power and smart power thus subvert positive power analysis, albeit unintentionally. Rather than conceiving of soft power as a concept that parallels hard power, we could more usefully conceive of soft power as part of the preference formation process. The concept usefully underscores the fact that preference formation is not entirely a domestic process. External actors, transnational relations, and flows of information, norms, and ideas also affect state preference formation. As Moravcsik (2008) writes, states are embedded in the globalized economy and transnational society and these contexts shape state preferences. Economic growth, the evolution of trade and capital markets, and technical advances can reshape preferences in ways that are quite separate from influence attempts.

How, as analysts, should we assign cross-border economic effects to these different concepts of power and preference formation? Whether these external influences should be placed in the basket of "power variables" or "preference determination" should rest on two tests: (1) whether the effect can be manipulated by external actors, governments in particular, and (2) whether the impact is intentional. If it is not intentional and cannot be manipulated-and certainly if it is not in the interest of the supposedly dominant state-it should not be assigned to the power category but rather to preference formation.

\section{SECTION SIX: CONCLUSION}

This paper has examined the exchange rate regimes of East Asian countries and assessed the relative value of the structural power and domestic political economy approaches in explaining regime choice. It examined the cumulative changes in exchange rates since the Chinese shift to a controlled appreciation in July 2005 and conducted a formal econometric test of the weights of key currencies in the implicit baskets of East Asian states. It finds that four of the larger economies of Southeast Asia have formed a loose but effective "renminbi bloc" with China, while Indonesia and Taiwan have followed the US dollar more closely. The Japanese yen and Korean won have tended to float relatively independently, with the won tracking the renminbi somewhat more closely since the global financial crisis.

Despite their broad appeal, structural power explanations do not seem to be well-equipped to explain the emergence of this renminbi bloc or the pattern of reserve accumulation and competitive 
currency valuation witnessed in East Asia. Among other reasons, the "structural" role of the dollar in East Asia is better suited to explaining continuity than the change in exchange rate regimes that we observe in the region. A common narrative within the region about the constraints imposed by the US dollar and the consequent need to escape them in order to achieve macroeconomic and monetary stability, while colorful, is correspondingly misleading.

Instead, the countries of East Asia have chosen their exchange rate regimes freely, according to the preferences determined by domestic political and financial structures and their position in the international trading system. Asian authorities chose highly competitive currency valuations over the expressed opposition of US authorities, not because Asian countries were subject to US hegemony. Their behavior is better described as free riding than submission. The shift in exchange rate policy on the part of Asian countries away from the dollar and toward renminbi coincides with the economic rise of China. But the shift does not reflect inducement or coercion on the part of Chinese authorities, who, to the contrary, communicate very little of their exchange rate preferences or intentions to their regional neighbors.

Nor does Chinese structural power offer an explanation that coincides with Chinese interests or could be consistent with the role of the US dollar, which remains dominant as an international currency. Southeast Asian monetary authorities instead adjusted their policies autonomously in light of the greater weight of China in their trade and production networks. Shadowing the gradual appreciation of the renminbi against the dollar, Southeast Asian countries have responded to China in an asymmetrical leader-follower relationship. The role of the dollar within the region has greatly facilitated this form of cooperation. Thus, Southeast Asian states have preserved competitiveness against Chinese competitors while moderating the domestic consequences (financial repression and inflation) of low valuation against the US dollar.

Currency relations in East Asia illustrate a number of more general points about power analysis. First, the prior step in power analysis must be to establish the preferences of actors. Without pinning down preferences first, we cannot assess the success of influence attempts. Second, some elements of economic transformation are better conceptualized as part of preference formation than as the exercise of power. This paper argues that this is the case for economic growth and exchange rate regimes in East Asia. Third, as a corollary, it is essential to keep preferences and power conceptually distinct. Whatever the contributions of some of the concepts of structural power and soft power, they erode this distinction to the detriment of positive analysis.

This paper does not argue that power has not been relevant to currency relations in East Asia historically or that it will not be relevant in coming decades. To the contrary, it could well play an important role in regional monetary relations in the future. Nor do I dismiss the importance of power 
analysis generally. The paper argues instead that concepts of power that are configured separately from preference formation will be more testable and thus serve as a better basis for a cumulative research program. Concepts of power are likely to be more effective analytically if we avoid overloading them and we can do so by asking preferences to shoulder a substantial share of the burden of explanation.

\section{REFERENCES}

Andrews, David M., ed. 2006. International Monetary Power. Ithaca, NY: Cornell University Press.

Bachrach, Peter, and Morton S. Baratz. 1962. Two Faces of Power. American Political Science Review 56, no. 4: 947-52.

Bergsten, C. Fred, and Joseph Gagnon. 2012. The Rise of ASEAN, China, and India: Implications for Europe and the United States. Manuscript. Washington: Peterson Institute.

Cavoli, Tony, and Ramkishen S. Rajan. 2009. Exchange Rate Regimes and Macroeconomic Management in Asia. Hong Kong: Hong Kong University Press.

Cohen, Benjamin J. 1977. Organizing the World's Money: The Political Economy of International Monetary Relations. New York: Basic Books.

Cohen, Benjamin J. 2008. After the Fall: East Asian Exchange Rates Since the Crisis. In Crisis as Catalyst: Asia's Dynamic Political Economy, eds. Andrew MacIntyre, T.J. Pempel, and John Ravenhill. Ithaca, NY: Cornell University Press.

Cohen, Benjamin J. Forthcoming. The Yuan's Long March: Can an International Currency Be

Manufactured? In Power in a Changing World Economy: Lessons from Emerging Asia, edited by Benjamin J. Cohen and Eric M. P. Chiu.

Cohen, Benjamin J., and Eric M. P. Chiu, eds. Forthcoming. Power in a Changing World Economy: Lessons from Emerging Asia.

Dooley, Michael, David Folkerts-Landau, and Peter Garber. 2003. An Essay on the Revived Bretton Woods System. NBER Working Paper 9971. Cambridge, MA: National Bureau of Economic Research.

Eichengreen, Barry. 2011. Exorbitant Privilege: The Rise and Fall of the Dollar and the Future of the International Monetary System. New York: Oxford University Press.

Frankel, Jeffrey, and Daniel Xie. 2010. Estimation of De Facto Flexibility Parameter and Basket Weights in Evolving Exchange Rate Regimes. PIIE Working Paper Series WP10-1. Washington: Peterson Institute for International Economics.

Frankel, Jeffrey, and Shang-Jin Wei. 1994. Yen Bloc or Dollar Bloc? Exchange Rate Policies of the East Asian Economies. In Macroeconomic Linkages: Savings, Exchange Rates and Capital Flows, eds. Takatoshi Ito and Anne O. Krueger. Chicago: University of Chicago Press.

Frankel, Jeffrey, and Shang-Jin Wei. 2007. Assessing China's Exchange Rate Regime. Economic Policy 22, no. 51: 575-614.

Girardin, Eric. 2011. A De Facto Asian-Currency Unit Bloc in East Asia: It Has Been There but We Did Not Look for It. ADBI Working Paper Series 11/262. Tokyo: Asian Development Bank Institute.

Goldstein, Morris. 2006. Currency Manipulation and Enforcing the Rules of the International Monetary System. In Reforming the IMF for the $21^{\text {st }}$ Century, ed. Edwin M. Truman. Washington: Peterson Institute for International Economics. 
Goldstein, Morris, and Nicholas R. Lardy. 2005. China's Role in the Revived Bretton Woods System: A Case of Mistaken Identity. PIIE Working Paper 05-2. Washington: Peterson Institute for International Economics.

Goldstein, Morris, and Nicholas R. Lardy, eds. 2008. Debating China's Exchange Rate Policy. Washington: Peterson Institute for International Economics.

Grimes, William W. 2009. Currency and Contest in East Asia: The Great Power Politics of Financial Regionalism. Ithaca, NY: Cornell University Press.

Guzzini, Stefano. 1993. Structural Power. International Organization 47, no. 3): 443-78.

Hamada, Koichi, Beate Reszat, and Ulrich Volz, eds. 2009. Towards Monetary and Financial Integration in East Asia. Northampton, MA: Edward Elgar.

He, Dong. 2011. Asian Regional Policy Coordination. Speech. Asia Economic Policy Conference. San Francisco, CA: Federal Reserve of San Francisco.

Helleiner, Eric. 2006. Below the State: Micro-Level Monetary Power. In International Monetary Power, ed. David Andrews. Ithaca, NY: Cornell University Press.

Helleiner, Eric. 2009. Enduring Top Currency, Fragile Negotiated Currency: Politics and the Dollar's International Role. In The Future of the Dollar, eds. Eric Helleiner and Jonathan Kirshner. Ithaca, NY: Cornell University Press.

Henning, C. Randall. 1998. Systemic Conflict and Regional Monetary Integration: The Case of Europe. International Organization 52, no. 3: 537-73.

Henning, C. Randall. 2006. The Exchange Rate Weapon and Macroeconomic Conflict. In International Monetary Power, ed. David M. Andrews. Ithaca, NY: Cornell University Press, 117-138.

Henning, C. Randall, and Saori Katada. Forthcoming. Cooperation without Institutions: The Case of East Asian Currency Arrangements. In Asian Designs: Interests, Identities and States in External Institutions, ed. Saadia Pekkanen. Palo Alto, CA: Stanford University Press.

Henning, C. Randall, and Mohsin Khan. 2011. Asia and Global Financial Governance. PIIE Working Paper 11-16. Washington: Peterson Institute for International Economics.

Ito, Takatoshi. 2008. Influence of the Renminbi on Exchange Rate Policies of Other Asian Countries. In Debating China's Exchange Rate Policy, eds. Morris Goldstein and Nicholas R. Lardy. Washington: Peterson Institute for International Economics.

James, Scott C., and David A. Lake. 1989. The Second Face of Hegemony: Britain's Repeal of the Corn Laws and the American Walker Tariff of 1846. International Organization 43 no. 1: 1-29.

Katada, Saori N. 2004. Japan's Counterweight Strategy: U.S.-Japan Cooperation and Competition in International Finance. In Beyond Bilateralism: U.S.-Japan Relations in the New Asia-Pacific, eds. Ellis S. Krauss and T. J. Pempel. Stanford, CA: Stanford University Press.

Katada, Saori N. 2008. From a Supporter to a Challenger? Japan's Currency Leadership in Dollar-dominated East Asia. Review of International Political Economy 15, no. 3: 399-417.

Kawai, Masahiro. 2007. Dollar, Yen, or Renminbi Bloc? In Toward an East Asian Exchange Rate Regime, eds. Duck-Koo Chung and Barry Eichengreen. Washington: Brookings Institution Press.

Kawai, Masahiro. 2011. Scope for Regional Exchange Rate Policy Coordination in Asia. Paper presented to the SEACEN-CEMLA conference in Kuala Lumpur, October 13-15. Tokyo: Asian Development Bank Institute.

Kawai, Masahiro, and Shinji Takagi. 2005. Strategy for a Regional Exchange Rate Arrangement in East Asia: Analysis, Review and Proposal. Global Economic Review 34 no. 1:21-64. 
Kenen, Peter B., and Ellen Meade. 2008. Regional Monetary Integration. New York: Cambridge University Press.

Keohane, Robert. 2000. Forward. In Strange Power: Shaping the Parameters of International Relations and International Political Economy, eds. Thomas C. Lawton, James N. Rosenau, and Amy Verdun. Aldershot: Ashgate.

Kirshner, Jonathan. 2003. States, Markets, and Great Power Relations in the Pacific: Some Realist Expectations. In International Relations Theory and the Asia-Pacific, edited by G. John Ikenberry and Michael Mastanduno. New York: Columbia University Press.

Kirshner, Jonathan. 2009. After the (Relative) Fall: Dollar Diminution and the Consequences for American Power. In The Future of the Dollar, eds. Eric Helleiner and Jonathan Kirshner. Ithaca, NY: Cornell University Press.

Liew, Leong H., and Harry X. Wu. 2007. The Making of Chinese Exchange Rate Policy: From Plan to WTO Entry. Northampton, MA: Edward Elgar.

Lukes, Steven. 1974. Power: A Radical View. London: MacMillan.

Matsui, Kenichiro. 2008. Regional Monetary Units in East Asia and Latin America. Presented at the Annual Meeting of the American Political Science Association. Boston, MA. August 28-31.

Mattoo, Aaditya, Prachi Mishra, and Arvind Subramanian. 2012. Spillover Effects of Exchange Rates: A Study of the Renminbi. IMF Working Paper 12/88. Washington: International Monetary Fund.

McKinnon, Ronald I. 2005. Exchange Rates under the East Asian Dollar Standard: Living with Conflicted Virtue. Cambridge, MA: MIT Press.

McKinnon, Ronald I. 2013. The Unloved Dollar Standard: From Bretton Woods to the Rise of China. New York: Oxford University Press.

McKinnon, Ronald I., and Gunther Schnabl. 2004. The Return to Soft Dollar Pegging in East Asia: Mitigating Conflicted Virtue. International Finance 7, no. 2: 169-201.

McKinnon, Ronald I., and Gunther Schnabl. 2006. Current Account Surpluses and Conflicted Virtue in East Asia: China and Japan Under the Dollar Standard. In Towards Monetary and Financial Integration in East Asia, eds. Koichi Hamada, Beate Reszat, and Ulrich Volz. Northampton, MA: Edward Elgar.

Moravcsik, Andrew. 1997. Taking Preferences Seriously: A Liberal Theory of International Politics.

International Organization 51, no. 4: 513-53.

Moravcsik, Andrew. 2008. The New Liberalism. In The Oxford Handbook of International Relations, eds. Christian Reus-Smit and Duncan Snidal. New York: Oxford University Press.

Nye, Joseph S. 2008. The Powers to Lead. New York: Oxford University Press.

Nye, Joseph S. 2010. The Future of American Power: Dominance and Decline in Perspective. Foreign Affairs 89, no. 6: 2-12.

Nye, Joseph S. 2011. The Future of Power. New York: PublicAffairs.

Ogawa, Eiji. 2007. Regional Financial Cooperation in East Asia and the AMU. Keizai Sangyo Journal (METI Journal), July. Tokyo: Research Institute of Economy, Trade and Industry. Available at http://www.rieti.go.jp/en/ papers/research-review/040.html (accessed March 15, 2012).

Ogawa, Eiji, and Takatoshi Ito. 2002. On the Desirability of a Regional Currency Basket Arrangement. Journal of Japanese and International Economies 16, no. 3: 317-334. 
Palan, Ronen. 1999. Susan Strange 1923-1998: A Great International Relations Theorist. Review of International Political Economy 6, no. 2: 121-132.

Park, Yung Chul, and Chi-Young Song. 2011. Prospects for Monetary Cooperation in East Asia. ADBI Working Paper Series, No. 314. Asian Development Bank Institute, Tokyo, October.

Pauly, Louis W. 2011. Hong Kong's International Financial Centre: Retrospect and Prospect. Hong Kong: Savantas Policy Institute. Available at http://www.savantas.org/cmsimg/files/Research/HKIFC/Pauly_HongKongIFC_ StudyFinal.pdf (accessed March 15, 2012).

Shu, Chang. 2010. Impact of Renminbi on Asian Currencies. In Currency Internationalization: Global Experiences and Implications for the Renminbi, edited by Wensheng Peng and Chang Shu. London/New York: Palgrave Macmillan.

Shu, Chang, Nathan Chow, and Jun-yu Chan. 2007. Impact of the Renminbi Exchange Rate on Asian Currencies. Working Paper Series June. Hong Kong: Hong Kong Monetary Authority.

Steinberg, David. 2012. A Conditional Preference Theory of Undervalued Exchange Rates. Paper presented to the annual meeting of the International Studies Association, San Diego, CA, April.

Steinberg, David, and Victor Shih. 2012. Interest Group Influence in Authoritarian States: The Political Determinants of Chinese Exchange Rate Policy. Comparative Political Studies, available at http://cps.sagepub. com/content/early/2012/02/28/0010414012437168.

Strange, Susan. 1986. Casino Capitalism. Manchester: Manchester University Press.

Strange, Susan. 1988. States and Markets. London: Pinter.

Subramanian, Arvind. 2011. Eclipse: Living in the Shadow of China's Economic Dominance. Washington, Peterson Institute for International Economics.

Volz, Ulrich. 2009. Three Cases for Monetary Integration in East Asia. In Towards Monetary and Financial Integration in East Asia, eds. Koichi Hamada, Beate Reszat, and Ulrich Volz. Cheltenham, UK and Northampton, MA: Edward Elgar.

Volz, Ulrich. 2010. Prospects for Monetary Cooperation and Integration in East Asia. Cambridge, MA: MIT Press.

Willett, Thomas D., Yonghyup Oh, and Deok Ryong Yoon, eds. 2004. Monetary and Exchange Rate Arrangements in East Asia. Seoul: Korea Institute for International Economic Policy.

Willett, Thomas D., et al. 2011. Classifying International Aspects of Exchange Rate Regimes. Journal of Financial Economic Policy 3 no. 4: 288-303.

Williamson, John. 2005. A Currency Basket for East Asia, Not Just China. Policy Briefs in International Economics 05-1. Washington: Peterson Institute for International Economics.

Zhou, Xiaochuan. 2009. Reform of the International Monetary System. Basel: Bank for International Settlements. Available at http://www.bis.org/review/r090402c.pdf (accessed March 15, 2012). 
Figure 1 US dollars per national currency (index normalized at 100 in July 2005)

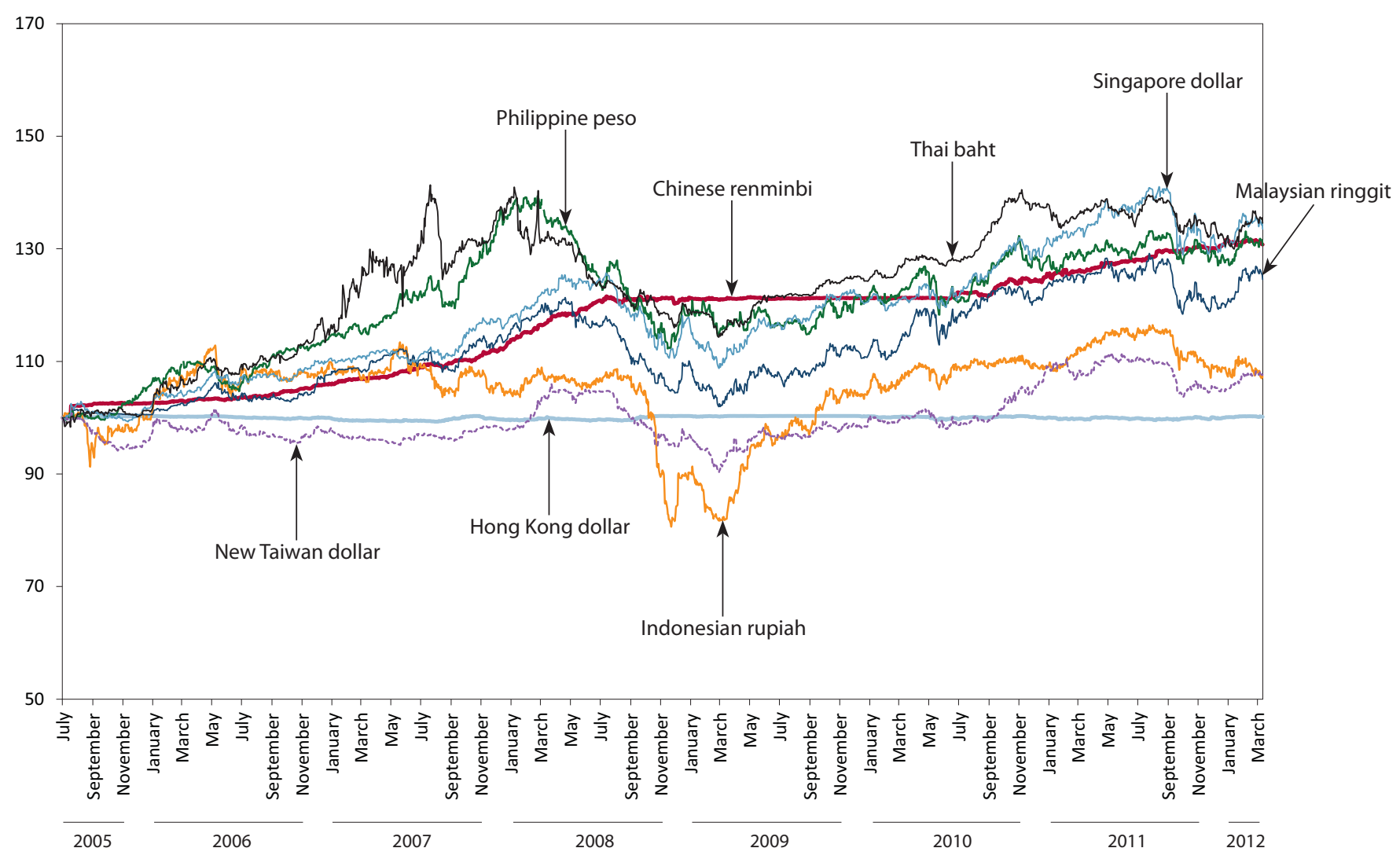

Note: An increase denotes an appreciation against the US dollar.

Source: University of British Columbia, Pacific Exchange Rates database. 
Figure 2 Bilateral real exchange rate against the US dollar (index normalized at 100 in July 2005)

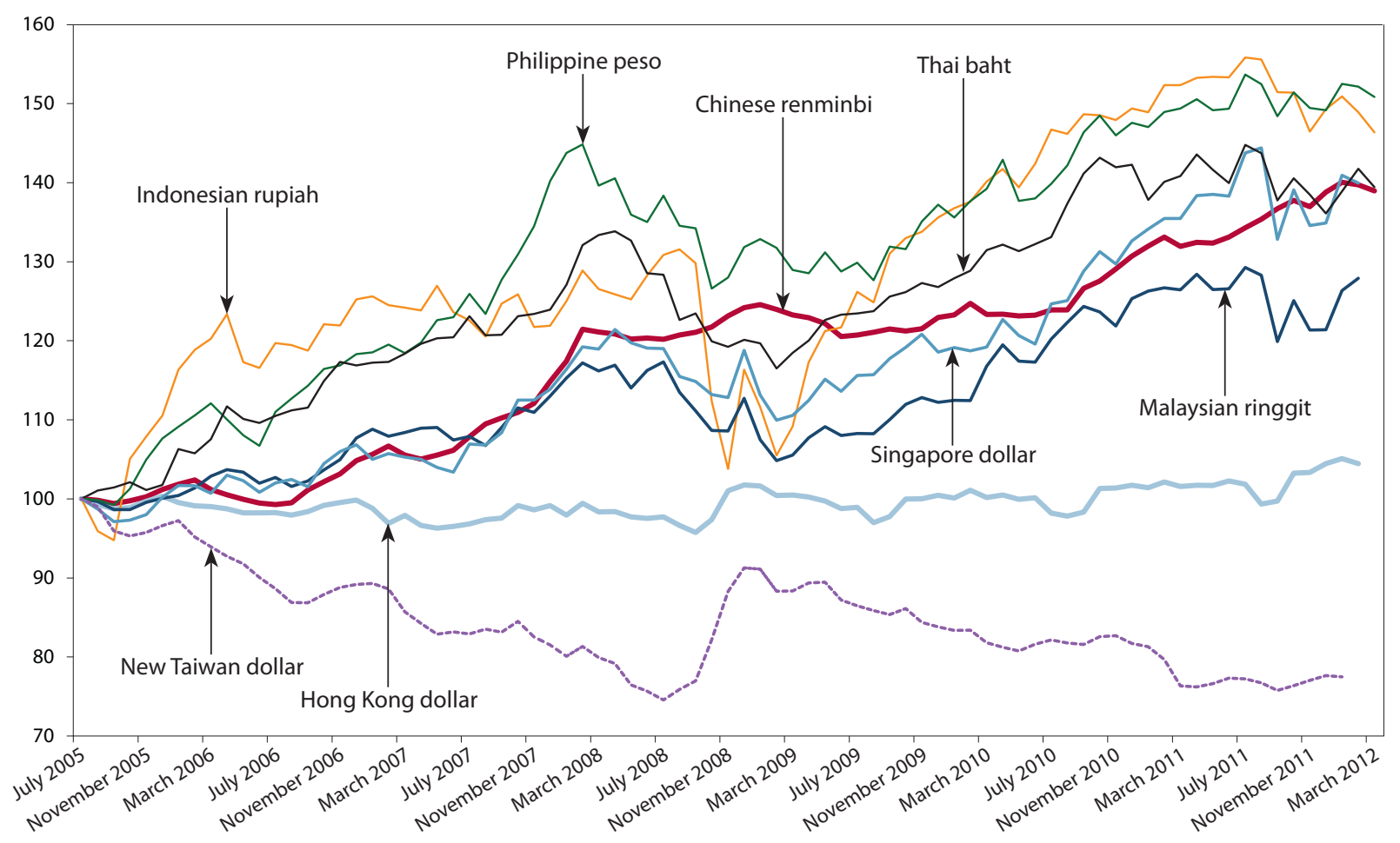

Note: Real Exchange Rate is computed using the Consumer Price Index.

Source: IMF International Financial Statistics; Chinese National Statistics for Chinese Consumer Price Index (CPI), Taiwanese National Statistics for Taiwanese data. 
Table 1 Estimated weights in East Asian currency baskets, January 1, 2000 to July 21, 2005

\begin{tabular}{|c|c|c|c|c|c|c|c|c|}
\hline & $\begin{array}{l}\text { Hong Kong } \\
\text { Dollar }\end{array}$ & $\begin{array}{l}\text { Indonesian } \\
\text { Rupiah }\end{array}$ & $\begin{array}{c}\text { Korean } \\
\text { Won }\end{array}$ & $\begin{array}{l}\text { Malaysian } \\
\text { Ringgit }\end{array}$ & $\begin{array}{l}\text { Philippine } \\
\text { Peso }\end{array}$ & $\begin{array}{c}\text { Singapore } \\
\text { Dollar }\end{array}$ & $\begin{array}{c}\text { New } \\
\text { Taiwan } \\
\text { Dollar }\end{array}$ & Thai Baht \\
\hline US Dollar & $\begin{array}{c}0.983^{* * *} \\
{[0.007]}\end{array}$ & $\begin{array}{c}0.562^{* *} \\
{[0.233]}\end{array}$ & $\begin{array}{c}0.548^{* * * *} \\
{[0.102]}\end{array}$ & $\begin{array}{l}1.006^{* * *} \\
{[0.008]}\end{array}$ & $\begin{array}{c}1.078^{* * *} \\
{[0.125]}\end{array}$ & $\begin{array}{c}0.558^{* * *} \\
{[0.049]}\end{array}$ & $\begin{array}{c}0.826^{* * *} \\
{[0.054]}\end{array}$ & $\begin{array}{l}0.697^{* * *} \\
{[0.068]}\end{array}$ \\
\hline Yen & $\begin{array}{c}0.004 \\
{[0.003]}\end{array}$ & $\begin{array}{l}-0.017 \\
{[0.094]}\end{array}$ & $\begin{array}{l}0.191 \text { *** } \\
{[0.041]}\end{array}$ & $\begin{array}{c}0.005 \\
{[0.003]}\end{array}$ & $\begin{array}{c}0.149^{* * *} \\
{[0.050]}\end{array}$ & $\begin{array}{l}0.204^{* * *} \\
{[0.020]}\end{array}$ & $\begin{array}{c}0.050^{* *} \\
{[0.022]}\end{array}$ & $\begin{array}{l}0.220^{* * *} \\
{[0.028]}\end{array}$ \\
\hline Euro & $\begin{array}{l}-0.003 \\
{[0.006]}\end{array}$ & $\begin{array}{l}-0.231 \\
{[0.185]}\end{array}$ & $\begin{array}{l}-0.211^{* * *} \\
{[0.081]}\end{array}$ & $\begin{array}{c}0.007 \\
{[0.007]}\end{array}$ & $\begin{array}{c}0.119 \\
{[0.099]}\end{array}$ & $\begin{array}{l}-0.008 \\
{[0.039]}\end{array}$ & $\begin{array}{l}-0.019 \\
{[0.043]}\end{array}$ & $\begin{array}{c}0.001 \\
{[0.054]}\end{array}$ \\
\hline Constant & $\begin{array}{l}-0.000 \\
{[0.000]}\end{array}$ & $\begin{array}{c}0.000 \\
{[0.000]}\end{array}$ & $\begin{array}{l}-0.000 \\
{[0.000]}\end{array}$ & $\begin{array}{c}0.000 \\
{[0.000]}\end{array}$ & $\begin{array}{c}0.000 \\
{[0.000]}\end{array}$ & $\begin{array}{l}-0.000 \\
{[0.000]}\end{array}$ & $\begin{array}{c}0.000 \\
{[0.000]}\end{array}$ & $\begin{array}{l}-0.000 \\
{[0.000]}\end{array}$ \\
\hline Observations & 1383 & 1377 & 1383 & 1383 & 1383 & 1383 & 1383 & 1383 \\
\hline $\begin{array}{l}\text { Adjusted } \\
R \text {-squared }\end{array}$ & 0.989 & 0.052 & 0.231 & 0.984 & 0.198 & 0.400 & 0.517 & 0.332 \\
\hline
\end{tabular}

Note: Standard errors in brackets. ${ }^{*} p<0.10,{ }^{* *} p<0.05, * * * p<0.01$.

Sources: Pacific Exchange Rate Service (http://fx.sauder.ubc.ca/data.html), author's computations.

Table 2 Estimated weights in East Asian currency baskets, July 22, 2005 to July 2, 2009

\begin{tabular}{|c|c|c|c|c|c|c|c|c|}
\hline & $\begin{array}{l}\text { Hong Kong } \\
\text { Dollar }\end{array}$ & $\begin{array}{l}\text { Indonesian } \\
\text { Rupiah }\end{array}$ & $\begin{array}{c}\text { Korean } \\
\text { Won }\end{array}$ & $\begin{array}{l}\text { Malaysian } \\
\text { Ringgit }\end{array}$ & $\begin{array}{l}\text { Philippine } \\
\text { Peso }\end{array}$ & $\begin{array}{l}\text { Singapore } \\
\text { Dollar }\end{array}$ & $\begin{array}{c}\text { New } \\
\text { Taiwan } \\
\text { Dollar }\end{array}$ & Thai Baht \\
\hline \multirow[t]{2}{*}{ US Dollar } & $0.980^{* * *}$ & -0.018 & 0.085 & 0.087 & $0.457^{* * *}$ & 0.025 & $0.270^{* *}$ & 0.340 \\
\hline & {$[0.013]$} & {$[0.284]$} & {$[0.400]$} & [0.129] & {$[0.166]$} & [0.100] & [0.114] & {$[0.236]$} \\
\hline \multirow[t]{2}{*}{ Yen } & $0.008^{* * * *}$ & $-0.258^{* * *}$ & $-0.523^{* * *}$ & $-0.109^{* * *}$ & $-0.173^{* * *}$ & $-0.072^{* * *}$ & $-0.059 * * *$ & $-0.081^{*}$ \\
\hline & {$[0.003]$} & {$[0.055]$} & {$[0.078]$} & {$[0.025]$} & {$[0.032]$} & {$[0.019]$} & {$[0.022]$} & {$[0.046]$} \\
\hline \multirow[t]{2}{*}{ Euro } & 0.003 & $-0.385^{* *}$ & -0.319 & -0.039 & $-0.189^{*}$ & $0.152^{* *}$ & -0.062 & -0.202 \\
\hline & {$[0.009]$} & [0.187] & {$[0.262]$} & [0.084] & [0.109] & [0.066] & {$[0.074]$} & [0.155] \\
\hline \multirow[t]{2}{*}{ Renminbi } & 0.011 & 0.305 & -0.018 & $0.624^{* * *}$ & 0.142 & $0.485^{* * *}$ & $0.429 * * *$ & 0.164 \\
\hline & {$[0.011]$} & {$[0.233]$} & {$[0.328]$} & [0.106] & [0.136] & [0.082] & [0.093] & [0.194] \\
\hline \multirow[t]{2}{*}{ Constant } & 0.000 & 0.000 & 0.000 & 0.000 & -0.000 & -0.000 & 0.000 & -0.000 \\
\hline & {$[0.000]$} & {$[0.000]$} & {$[0.000]$} & {$[0.000]$} & {$[0.000]$} & {$[0.000]$} & {$[0.000]$} & {$[0.000]$} \\
\hline Observations & 988 & 988 & 988 & 988 & 984 & 988 & 988 & 988 \\
\hline $\begin{array}{l}\text { Adjusted } \\
\quad R \text {-squared }\end{array}$ & 0.990 & 0.098 & 0.087 & 0.377 & 0.291 & 0.239 & 0.432 & 0.127 \\
\hline
\end{tabular}

Note: Standard errors in brackets. ${ }^{*} p<0.10,{ }^{* *} p<0.05,{ }^{* * *} p<0.01$

Sources: Pacific Exchange Rate Service (http://fx.sauder.ubc.ca/data.html), author's computations. 
Table 3 Estimated weights in East Asian currency baskets, July 2, 2009 to June 18, 2010

\begin{tabular}{lcccccccc}
\hline & $\begin{array}{c}\text { Hong Kong } \\
\text { Dollar }\end{array}$ & $\begin{array}{c}\text { Indonesian } \\
\text { Rupiah }\end{array}$ & $\begin{array}{c}\text { Korean } \\
\text { Won }\end{array}$ & $\begin{array}{c}\text { Malaysian } \\
\text { Ringgit }\end{array}$ & $\begin{array}{c}\text { Philippine } \\
\text { Peso }\end{array}$ & $\begin{array}{c}\text { Singapore } \\
\text { Dollar }\end{array}$ & $\begin{array}{c}\text { New } \\
\text { Taiwan } \\
\text { Dollar }\end{array}$ & $\begin{array}{c}\text { Thai Baht } \\
\text { US Dollar }\end{array}$ \\
\hline $0.978^{* * *}$ & $0.874^{* * *}$ & 0.541 & 0.418 & $0.863^{* * *}$ & 0.211 & $0.589^{* * *}$ & $0.839^{* * *}$ \\
& {$[0.020]$} & {$[0.329]$} & {$[0.431]$} & {$[0.269]$} & {$[0.275]$} & {$[0.137]$} & {$[0.152]$} & {$[0.089]$} \\
Yen & -0.008 & -0.059 & $-0.270^{* *}$ & $-0.281^{* * *}$ & -0.125 & $-0.186^{* * *}$ & $-0.138^{* * *}$ & -0.001 \\
& {$[0.006]$} & {$[0.099]$} & {$[0.129]$} & {$[0.081]$} & {$[0.083]$} & {$[0.041]$} & {$[0.046]$} & {$[0.027]$} \\
Euro & -0.012 & 0.263 & 0.382 & -0.151 & 0.339 & -0.142 & -0.088 & 0.047 \\
& {$[0.019]$} & {$[0.309]$} & {$[0.405]$} & {$[0.252]$} & {$[0.258]$} & {$[0.129]$} & {$[0.143]$} & {$[0.083]$} \\
Constant & 0.000 & $-0.001^{*}$ & -0.001 & $-0.001 *$ & -0.000 & -0.000 & -0.000 & -0.000 \\
& {$[0.000]$} & {$[0.000]$} & {$[0.000]$} & {$[0.000]$} & {$[0.000]$} & {$[0.000]$} & {$[0.000]$} & {$[0.000]$} \\
Observations & 242 & 242 & 242 & 242 & 242 & 242 & 242 & 242 \\
Adjusted & 0.988 & 0.106 & 0.104 & 0.193 & 0.162 & 0.263 & 0.404 & 0.722 \\
R-squared & & & & & & & & \\
\hline
\end{tabular}

Note: Standard errors in brackets. ${ }^{*} p<0.10,{ }^{* *} p<0.05,{ }^{* * *} p<0.01$

Sources: Pacific Exchange Rate Service (http://fx.sauder.ubc.ca/data.html), author's computations.

Table 4 Estimated weights in the East Asian currency baskets, June 18, 2010 to December 30, 2011

\begin{tabular}{|c|c|c|c|c|c|c|c|c|}
\hline & $\begin{array}{l}\text { Hong Kong } \\
\text { Dollar }\end{array}$ & $\begin{array}{l}\text { Indonesian } \\
\text { Rupiah }\end{array}$ & $\begin{array}{c}\text { Korean } \\
\text { Won }\end{array}$ & $\begin{array}{c}\text { Malaysian } \\
\text { Ringgit }\end{array}$ & $\begin{array}{c}\text { Philippine } \\
\text { Peso }\end{array}$ & $\begin{array}{l}\text { Singapore } \\
\text { Dollar }\end{array}$ & $\begin{array}{c}\text { New } \\
\text { Taiwan } \\
\text { Dollar }\end{array}$ & Thai Baht \\
\hline \multirow[t]{2}{*}{ US Dollar } & $0.893^{* * *}$ & $0.702^{* * * *}$ & $-0.507^{*}$ & -0.085 & 0.063 & $-0.265^{*}$ & 0.212 & 0.170 \\
\hline & {$[0.021]$} & {$[0.247]$} & {$[0.292]$} & {$[0.196]$} & {$[0.179]$} & [0.159] & {$[0.140]$} & {$[0.135]$} \\
\hline \multirow[t]{2}{*}{ Yen } & $-0.009^{*}$ & 0.030 & $-0.275^{* * *}$ & $-0.133^{* * *}$ & $-0.077^{*}$ & $-0.126^{* * *}$ & -0.056 & -0.029 \\
\hline & {$[0.005]$} & {$[0.062]$} & {$[0.074]$} & [0.049] & {$[0.045]$} & {$[0.040]$} & {$[0.035]$} & {$[0.034]$} \\
\hline \multirow[t]{2}{*}{ Euro } & 0.004 & 0.010 & -0.130 & 0.015 & 0.067 & 0.030 & 0.026 & -0.038 \\
\hline & {$[0.014]$} & [0.169] & {$[0.200]$} & [0.134] & {$[0.122]$} & [0.109] & {$[0.095]$} & [0.092] \\
\hline \multirow[t]{2}{*}{ Renminbi } & $0.080^{* * *}$ & 0.237 & $0.646^{* * *}$ & $0.774 * * *$ & $0.694^{* * *}$ & $0.374 * * *$ & $0.492^{* * *}$ & $0.339 * * *$ \\
\hline & {$[0.014]$} & {$[0.170]$} & {$[0.201]$} & {$[0.135]$} & [0.123] & [0.109] & {$[0.096]$} & [0.093] \\
\hline \multirow[t]{2}{*}{ Constant } & 0.000 & 0.000 & 0.000 & -0.000 & -0.000 & -0.000 & -0.000 & -0.000 \\
\hline & {$[0.000]$} & {$[0.000]$} & {$[0.000]$} & {$[0.000]$} & {$[0.000]$} & {$[0.000]$} & {$[0.000]$} & {$[0.000]$} \\
\hline Observations & 468 & 468 & 468 & 468 & 468 & 468 & 468 & 468 \\
\hline $\begin{array}{l}\text { Adjusted } \\
R \text {-squared }\end{array}$ & 0.982 & 0.259 & 0.071 & 0.254 & 0.285 & 0.066 & 0.373 & 0.291 \\
\hline
\end{tabular}

Note: Standard errors in brackets. ${ }^{*} p<0.10,{ }^{* *} p<0.05,{ }^{* * *} p<0.01$

Sources: Pacific Exchange Rate Service (http://fx.sauder.ubc.ca/data.html), author's computations. 